\title{
Muslim Personal Law And Gender Equality Concerns In India
}

\author{
Saadiya \\ Faculty of Law, Jamia Millia Islamia, \\ New Delhi-25, India. \\ saadiya@jmi.ac.in
}

\begin{abstract}
Personal laws are mired with controversies on questions of gender equality. In India, where each community is governed by its own sets of personal laws, Muslim Personal Law, especially, is perceived to further gender inequality. This paper analyses such gender inequality concerns about the Muslim personal laws in context of property rights and right of dissolution of marriage. This paper argues that gender inequality in India stems from deep rooted cultural patriarchy without having any religious backing and such inequality is further endorsed by discriminatory laws. This paper argues that the despicable condition of Muslim women in India is due to ignorance of usul-ul-fiqh because of which they do not assert the rights guaranteed to them by Islam. Lack of knowledge of usul-ul-fiqh perpetuates the prevalent popular misconception of Muslim personal law as being oppressive to woman when in reality it gives them equal rights.
\end{abstract} Islam.

Keywords-Muslim personal law; India; Gender equality;

\section{INTRODUCTION}

Much to the bewilderment of many, rooting for the ideals of equality, laws are still classified on the basis of religious identities in India. Although the Constitution of India is built up on a "secular" edifice,[1] religion cannot be divorced from the ground realities of Indian political system. Even though Article 44 [2] of the Indian Constitution envisages a Uniform Civil Code for its citizens, each community is governed by its own set of personal laws. Laws governing Hindus, Christians and Parsis are codified by the legislature whereas the Muslim Personal Law is largely uncodified. Since the laws are based on religious texts and customs, the differences between different personal laws are stark, affecting the rights of two individuals similarly situated to extremely different set of laws just because they belong to different religions [3].

Given the backward, under developed social status of Muslims in general in India, as pointed out by the Sacchar Committee Report, [4] along with the projection of Muslim societies as being vehicles of suppression of human rights, women's rights under Muslim Personal law have been the subject of a great debate. There is this overwhelming tendency in India to blame Islam for laws which are viewed as immensely oppressive to women. In absence of codified Muslim personal law in India and popular misconception of viewing Islamic law as a homogeneous entity, the task of delivering justice to Muslim women in India is left at the hands of judiciary which in its hypocrisy has treated the Muslim personal law as untouchable, at the same time reforming other minority/majority personal laws. This paper is a small attempt of analysing the Muslim personal law in India addressing the gender inequality issues, viewing the same with the lens of $u s u l-u l$ fiqh. The scope of this paper is restricted to gender equality concerns only with respect to property rights and the right of dissolution of marriage.

\section{MuSLIM PERSONAL LAW AND GENDER EQUALITY CONCERNS IN INDIA.}

The subject of Muslim Personal Law in India poses unique challenges keeping in mind the legal framework and the peculiar socio-political conditions existing in the country. Laws in Indian legal system are either applicable on the basis of territorial jurisdictions [5] or on the basis of religious identities [6]. Laws governing marriage and divorce; infants and minors; adoption; wills, intestacy and succession; joint family and partition are essentially governed by the Personal laws of the parties. Entry 5, List III of Seventh Schedule of the Constitution makes it competent for either the State or the Union Legislature to legislate on topics falling within the purview of the personal laws [7]. The codification process of various personal laws in India began during the British with Parsi Law [8] and Christian Law [9] of marriage and divorce being codified along with piecemeal legislation pertaining to Hindu Women's right to property [10]. The process of codification of Hindu Law on a larger scale began in 1930's which finally culminated into the passing of the Hindu Code Bill in 1956 with the coming into existence of four statutes dealing with various aspects of personal laws of Hindus [11]. With respect to Muslims, there are two major preindependence pieces of legislations- the Muslim Personal Law (Shariat) Application Act, 1937 and the Dissolution of Muslim Marriage Act, 1939. The Shariat Act is the source of validation of application of Shariat law to Muslims on question of marriage, divorce, maintenance, adoption, succession etc.

Keeping in mind the ongoing debate in India over the enactment of a uniform civil code for all communities on the pretext of alleged oppression of Muslim women by application of Shariat on them, it becomes extremely important for us to understand what the application of Shariat on Indian women implies. 


\section{A. Property rights and Gender equality concerns in India}

Financial independence is an important determinant when it comes to gender equality concerns. Right to property is one of the most important factors in emancipation and empowerment of women. Prior to the enactment of 'The Shariat Act, 1937', lot of Quranic rights guaranteed to the women were defeated by upholding contrary customary practices, especially, in context of property related rights [12]. The Act was enacted to clarify that customs cannot override Muslim Law. The Act provided for an injunction upon the court in situations when any question relating to, intestate succession, properties of female, dissolution of marriage is in issue and where the parties are Muslims, to apply the Muslim personal law (Shariat) irrespective of any contrary custom or usage [13]. Here, what is important to understand is that, at the time in a very patriarchal Indian society, women as a class did not have a lot of rights. A Hindu woman could not be a coparcener [14] and had very limited right to property [15]. Certain communities amongst the Muslims who were converts from Hinduism, had retained their pre-conversion local laws and customs. For example, the Bohras, the Khojas and the Kutchi Memons of Gujarat followed the Hindu law of coparcenary. Under the Islamic Law of succession, women like men had fixed share in the inheritance. This proposition of women having a share in the property rights was not and is still not to a very large extent acceptable to the majorly patriarchal society. As highlighted by the research conducted by Faculty of Law, Jamia Millia Islamia in collaboration with National Commission of Women on Discriminative and Derogatory Practices against women by Khap Panchayats, Shailashi Adalats and Kangaroo Courts in India: An Empirical Study in the States of Haryana, Uttar Pradesh (West), West Bengal \& Rajasthan, women are expected to transfer the property in the names of male members of the family prior to getting married. [16]

The most important thing highlighted by the report was that, in rural north India where the research was conducted, Muslim women either did not know of the inheritance right granted to them by Shariat or even if they knew, they gave up their rights for the fear of souring relationship with the family. The patriarchal forces in the society are far too strong which when clubbed with the fundamentalist powers in the society, gag the voice of women not only in order to boost their inflated male egos but also to control the property rights. When this status is compared to that of Muslim women during the life of the Prophet, the contrast is shocking. Early Muslim women were actively involved in every aspect of the life of the nascent Muslim society [17]. They included business women, poets, jurists, religious leaders and even warriors [18]. The contemporary perception of Muslim women, especially in India, being restricted to household chores, is disheartening.

Under Islamic law of inheritance, the women get half the inheritance which their brothers get. It is pertinent to note that the general perception with regards to the inheritance laws being discriminatory owing to the said difference, overlooks the fact that women under Islamic law inherit in different capacities, both as sharers as well as residuaries. To critically examine patriarchal Islamic jurisprudence from within the tradition, a woman must be familiar with the logic of usul al- fiqh [19]. This requirement is difficult to satisfy as patriarchy has drastically reduced women's access to the arena of Islamic jurisprudence despite the women's early involvement and contribution to it [20]. Consequently, the demand for the education of women, particularly in the area of religious studies, is critical. In India, where even Muslim men do not have any understanding of usul al-fiqh, situation of women, who neither have access to western education nor religious education, becomes essentially hopeless. Often, women do not get what is lawfully theirs due of lack of awareness and cheating by her brothers [21]. Mostly, familial pressure and the fear of upsetting brothers whom she might have to approach in case of divorce, prevents her from staking her share [22].

It is also to be noted that even though customs were overruled by application of Shariat Act for the purpose of intestate succession, agricultural land was specifically kept out of the purview of the same [23]. The situation is identical with respect to Hindu law wherein the codified law i.e., Hindu Succession Act does not override any other law in force for agricultural land [24]. Patriarchal norms are thus, legally endorsed in case of both Hindu as well as Muslim women. It can very well be concluded that gender inequality, especially in context of property rights, stems from the cultural context rather than having any religious backing.

\section{B. Dissolution of Marriage and Gender Equality Concerns in India}

The 1939 Act was enacted specifically with the object of consolidating and clarifying the provisions of Muslim law relating to suits for dissolution of marriage, by women married under Muslim law and to remove doubts as to the effect of the renunciation of Islam by a married Muslim woman on her marriage tie [25]. The Act was enacted specifically for dealing with peculiar social realities of that time existing among Muslim women who having no other option would convert to Hinduism in order to dissolve their marriage [26]. As per the Act, on renunciation of Islam by the wife, marriage shall not come to an end ipso facto [27]. The Act which was brought into existence in order to provide Muslim women matrimonial remedy for purpose of dissolution of marriage poses a unique problem, wherein for the purpose of assessing effect on marriage, husbands' apostasy is governed by uncodified Muslim law which dissolves the marriage ipso facto whereas, wife's apostasy is governed by the Act which does not dissolve the marriage. Such convert wife is however, entitled to obtain a decree of dissolution under the Act. This leads to a peculiar situation where on subject of conversion from Islam, men and women are governed by three distinct set of laws. On question other than marriage, both are governed by the Caste Disabilities Removal Act, 1950 by virtue of which their preconversion inheritance rights are not affected. On question of marriage status, men are governed by Shariat and women by the Dissolution of Muslim Marriage Act, 1939.

It is important to note that the enactment of both these Acts by the British was at the insistence of the Muslim community, for the purpose of restoring Islamic position in place of the customary laws governing them, which caused denial of 
rights, especially to women. It is also pertinent to note that, despite rule by Muslim rulers in India for centuries, all aspects of Islamic Private law was not enforced to Muslims, leaving the scope of adoption of various customs and usages by those Muslims. Thus, the converts had retained customs and usages in their dealings. It was these customary laws, conflicting with the rights guaranteed by Islam and causing hardship to Muslims, especially women, which the community wanted to rectify. It is imperative to note that, at the time of enactment of the Act, Hindu women in India had no matrimonial remedy available to them for dissolution of marriage. It was only after the enactment of the Hindu Marriage Act in 1956 that Hindu women became entitled to divorce their husbands on any of the fault grounds provided in the Act [28].

The 1939 Act, which enabled women to seek divorce on grounds enumerated therein, a residuary clause entitling the wife to seek dissolution of her marriage through a court, on any other ground recognized as valid for the dissolution of marriages under Muslim law was also provided [29]. Thus, Khula, is recognized as a mode of dissolution of divorce for Muslim women. However, Khula or the Muslim Wife's right to dissolve the marriage remains highly under discussed in India. The misconceptions regarding Khula are rooted in the misinterpretation of the Quranic verses [30] as well as the Hadith [31] by various scholars [32]. The traditional understanding of Khula in the Indian subcontinent has been that the consent of the husband cannot be dispensed away with. This misconception is rooted in the Hanafi interpretation of the hadith in context of Khula [33].

It is important for us to remember that the basis of Islamic Law originates in two major sources, namely, divine revelation (wahy) and human reason (aql) [34]. This dual identity is reflected in the two expressions Shariah and fiqh. It is important to keep in mind that the Islamic jurisprudence has developed from four roots (usul al-fiqh):- (1) The Quran; [35] (2) the hadith or sunna; [36] (3) Ijma [37] and (iv) Qiyas [38]. Employing these usul al-fiqh, the Ulema [39] conducted a scientific and systematic inquiry. This is known as the process of ijtihad. Through this process of ijtihad sprung out various schools of law, each of which owed its existence to a renowned master [40]. These are the Sunni schools. Similarly, there are Shia schools, such as the Ithna Ashari, Jaffariya and Ismaili schools.

In India, Muslims are predominantly sunnis and by and large, follow the Hanafi school. The shias in India largely follow the Ithna Ashari school. The traditional shari'ah law is based on the concept of justice. In essence, the Shariat is a compendium of rules guiding the life of a Muslim from birth to death in all aspects of law, ethics and etiquette [41]. These rules have been crystallized through the process of ijtihad employing the sophisticated jurisprudential techniques [42]. The primary source of all Islamic Law, however, remains to be the Quran, the Word of God. Yet, in matters not directly covered by the divine book, rules were developed looking to the hadith and upon driving a consensus. The differences arose between the schools because of reliance on different hadith, differences in consensus and differences on qiyas as the case may be. Thus, in context of khula, the same hadith has been interpreted differently by various schools in order to arrive at different conclusions, some to the detriment of the rights guaranteed to women.

Pakistani Supreme Court unlike the Indian Supreme Court has been very progressive and courageous in interpreting the Quran and Sunnah, in order to provide remedy to the Muslim wives [43]. The Courts in Pakistan by resorting to ijtihad, have asserted their right to independent interpretation of the Qurān and Sunnah, where necessary; and their right to differ from the doctrines of traditionally authoritative legal texts of the various schools of thought in Islam, especially, the Hanafi school of thought [44]. In India, the focus has always been on the husbands' right to unilateral divorce or talaq, which is seen as the most arbitrary and unreasonable right guaranteed to a Muslim husband by the Shariat. Misconceptions about talaq in abundance, Khula has not even been in the academic discourse for a very long period of time. In context of the Muslim personal law, the judiciary, while adjudicating on constitutional validity of various codified personal laws, on one hand, has for long preferred to keep personal laws outside the ambit of "laws" as defined in Article 13 whenever it came to the uncodified Muslim personal laws, thereby refusing to test the constitutionality of same on the touchstone of Fundamental Rights [45]. The position stands little altered with the recent Shayara Bano judgment delivered by the Supreme Court of India holding talaq-ul-biddat as unconstitutional [46]. One very important aspect which the author wants to raise is the difference between the Pakistani superior courts and the Indian counterpart in terms of resorting to ijtihad or giving a fresh interpretation to Quran and Sunnah and the acceptance of such interpretation by the Muslim community in India. As it has been observed in the aftermath of Shahbano, [47] when the Muslim community was opposed to the idea of the Supreme Court interpreting verse 2:241 [48] of the Holy Quran, which led to the Parliament enacting the Muslim Women (Protection of Rights on Divorce) Act, 1986 with the intention of making the decision in Shah Bano's case ineffective.

It is also pertinent to note here that in Pakistan, the personal laws are codified, so as to make it easier for the superior courts to adjudicate upon the constitutionality of such laws on the touch stone of Shariah just like it did in the case of Saleem Ahmad [49] wherein the Federal Shariat Court held that section 10(4) of the impugned law was not found to be in conflict with any specific injunction contained in the Holy Qur'ān and Sunnah of the Holy Prophet (Peace Be Upon Him). In India, in absence of codification of substantive Muslim personal law, such actions on the part of the judiciary are bound to raise eyebrows.

\section{CONCLUSION}

Gender inequality in India stems from deep rooted cultural patriarchy as it is reflected in context of property rights, without having any religious backing. Such inequality is further endorsed by discriminatory laws. Deep rooted patriarchal mindset which pervades the Indian society, cutting across the religious lines, is the basic reason for gender inequalities. The law of dissolution of a Muslim marriage, at the instance of the wife has certain peculiarities in Indian context which in the given current socio-political scenario in 
the country, adds to the perceptible notions of gender inequality in Islam. Even though with the Shayra Bano judgement, a ray of hope has lighted that as misconceptions about talaq disappear, khula might also get a centre stage, it is yet to be seen how the community responds to the judgement. With respect to the despicable condition of the Muslim women in India, the basic reason remains the non assertion of rights which Shariat already guarantees them. This non assertion of rights is due to complete ignorance of the usul al-fiqh in Muslims, especially women. Popular misconceptions floating around in the media which paint a picture of Shariat as being oppressive towards women, does not help the women at all rather it reinforces the patriarchy already inherent in the society. Absence of codification of Muslim personal law adds to the problem. A discourse on usul al-fiqh in India, in absence of codification, is neigh impossibility. It is extremely important that Muslims in India, both men and women, should be made aware of the usul al-fiqh so as to lessen the gender inequality existing in the society.

\section{REFERENCES}

[1] Even though it was only by the 42nd Constitutional Amendment Act that the word 'Secularism' was inserted to the Preamble the Supreme Court of India has recognized secularism as the 'basic structure of the constitution'. See Sikri, C.J in Keshvananda Bharti v. State of Kerala \& Another AIR 1973 SC 1461.

[2] Article 44 of the Constitution of India, 1950 reads- The State shall endeavour to secure for the citizens a uniform civil code throughout the territory of India.

[3] For instance, if a Hindu/Christian/Parsi man marries a second time in the life time of his first wife without divorcing her, the first wife can prosecute the Husband for Bigamy under the c riminal law (Section 494 of the Indian Penal Code, 1860 penalizes Bigamy) whereas a Muslim wife cannot do so in case the husband marries in her lifetime without divorcing her. Also, in such a situation, the second "Hindu" wife does not have any rights or remedies under matrimonial laws whereas a second "Muslim" wife has all the rights and remedies available to the first wife under the civil laws.

[4] A Report on Social, Economic and Educational Status of the Muslim Community of India by Prime Minister's High Level Committee Cabinet Secretariat Government of India November, 2006 available at

[5] http://mhrd.gov.in/sites/upload_files/mhrd/files/sachar_comm.pdf.

[6] For example -the Indian Penal Code, The Contract Act, The Income Tax Act, The Information Technology Act, 2000 etc.

[7] For example -The Hindu Marriage Act, The Parsi Marriage and Divorce Act, The Indian Christian Marriage Act etc.

[8] Entry 5, List III reads-"Marriage and divorce; infants and minors; adoption; wills, intestacy and succession; joint family and partition; all matters in respect of which parties in judicial proceedings were immediately before the commencement of this Constitution subject to their personal law."

[9] The Parsee Marriage and Divorce Act, 1865 (Act No. XV of 1865).

[10] The Indian Divorce Act, 1869 (Act IV of 1869).

[11] Married Women's Property Act, 1874.

[12] The Hindu Marriage Act, 1955, The Hindu Adoption and Maintenance Act, 1956, The Hindu Minority and Guardianship Act, 1956, The Hindu Succession Act, 1956.

[13] See Hirbae v. Sonbae (1853) POC 110 wherein women from Khoja and Kutchi Memon were disallowed to claim inheritance right to parental property as a part of local custom which denied women property rights in male headed coparcenaries.

[14] Section 2 of the Shariat Application Act reads- Application of Personal Law to Muslims.-- Notwithstanding any customs or usage to the contrary, in all questions (save questions relating to agricultural land) regarding intestate succession, special property of females, including personal property inherited or obtained under contract or gift or any other provision of Personal Law, marriage, dissolution of marriage, including talaq, ila, zihar, lian, khula and mubaraat, maintenance, dower, guardianship, gifts, trusts and trust properties, and wakfs (other than charities and charitable institutions and charitable and religious endowments) the rule of decision in cases where the parties are Muslims shall be the Muslim Personal Law (Shariat).

[15] The amendment in Hindu Succession Act in 2006 has made the daughter a coparcener.

[16] See Hindu Women's Right to Property Act, 1937.

[17] See Report Discriminative and Derogatory Practices against women by Khap Panchayats, Shailashi Adalats and Kangaroo Courts in India: An Empirical Study in the States of Haryana, Uttar Pradesh (West), West Bengal \& Rajasthan available at http://ncw.nic.in/pdfReports/ReportbyJamiaMilia.pdf.

[18] Azizah al-Hibri, "Islam, Law and Custom: Redefining Muslim Women's Rights," 12 Am. U. J. Int'l L. \& Pol'y 11997.

[19] Ibid.

[20] Ibid.

[21] Ibid.

[22] Asghar Ali Engineer, "Rights of Women and Muslim Societies," 7 NLSIU Bangalore - Socio-Legal Review 15(2011).

[23] Ibid.

[24] See section 2 of the Shariat Act, 1937. Supra note xii.

[25] See section 4(2) of the Hindu Succession Act, 1956 which reads- (2) For the removal of doubts it is hereby declared that nothing contained in this Act shall be deemed to affect the provisions of any law for the time being in force providing for the prevention of fragmentation of agricultural holdings or for the fixation of ceilings or for the devolution of tenancy rights in respect of such holdings.

[26] Statement of Object of the Dissolution of Muslim Marriage Act, 1939 (Act no. VIII of 1939).

[27] See Musst Khan Bibi v. Pir Shah 19 PR (1884) 353; Ghaus v. Mst. Fajji AIR 1915 Lah. 14; Rahmate v. Nikka AIR 1928 Lah. 954; Mst. Sardaran v. Allah Baksh AIR 1934 Lah 976; Sardar Muhammad v. Mst. Maryam Bibi AIR 1936 Lah. 666; Resham Bibi v. Khuda Baksh AIR 1938 Lah. 482.

[28] Section 4 of the Dissolution of Muslim Marriage Act, 1939 readsEffect of conversion to another faith- The renunciation of Islam by a married Muslim woman or her conversion to a faith other than Islam shall not be itself operate to dissolve her marriage: Provided that after such renunciation, or conversion, the woman shall be entitled to obtain a decree for the dissolution of her marriage on any of the grounds mentioned in Section 2: Provided further that the provisions of this section shall not apply to a woman converted to Islam from some other faith who re-embraces her former faith.

[29] See section 13 of the Hindu Marriage Act, 1956. Ground of Divorce by mutual consent was not in the statute book until the amendment in 1976.

[30] Section 2 (ix)-on any other ground which is recognised as valid for the dissolution of marriages under Muslim law.

[31] Qur'ānic verse 2:229, states: "Divorce can be pronounced twice: then, either honourable retention or kindly release should follow. (While dissolving the marriage tie) it is unlawful for you to take back anything of what you have given to your wives unless both fear that they may not be able to keep within the bounds set by Allah. Then, if they fear that they might not be able to keep within the bounds set by Allah, there is no blame upon them for what the wife might give away of her property to become released from the marriage tie."

[32] According to the report of Al-Bukhārī in his al-jāmi al-sahịh (The

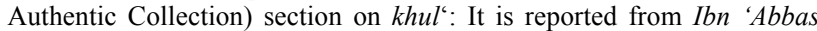
that the wife of Thäbit came to the Prophet (peace be upon him), and said: "I see no fault with Thäbit's conduct or his religious demeanour, but I dislike ingratitude in Islam." The Prophet (Peace Be Upon Him) said: "Will you return his garden to him?" "Yes", she answered. The messenger of Allah said: (to Thābit): "Accept (iqbil) your garden and divorce her [talliqha (once)]." 
[33] See Muhammad Munir, "The Law of Khul" in Islamic Law and the Legal System of Pakistan”, 2 LUMS Law Journal 33 (2015).

[34] According to Jașșās of the Hanafì school, the fact that both Thābit and Habiba were asked by the Prophet (Peace Be Upon Him) implies that $\mathrm{khul}^{\text {' }}$ is consensual because the husband has been placed at the center point in this episode, otherwise the Prophet could have dismissed him completely and divorced Habība entirely on his own. The Maliki's interpretation does not give much importance to the husband's consent. See ibid.

[35] Mohammad Hashim Kamali, Shari'ah Law: An Introduction, 40 (Oneworld Publication, Oxford, 2012).

[36] The Divine Book or the Word of God revealed by Angel Gabriel to Prophet Muhammad.

[37] The Prophet's pronouncements and practices as reported by his companions and his followers.

[38] Consensus of the Companions of the Prophet.

[39] Analogical reasoning.

[40] The learned in Islamic teachings, principles, law.

[41] For example, the jurisprudence (fiqh) developed by Abu Hanifah and continued by his disciples came to be known as the Hanafi school. The
Maliki school owed its origin to Malik b. Anas, the Shafie school to alShafi'i, the Hanbali school to Ibn-Hanbal and so on.

[42] Masroor Ahmed v. State (NCT of Delhi) and Anr. 2008(103) DRJ 137.

[43] Ibid.

[44] Saleem Ahmad v. The Government of Pakistan PLD 2014 FSC 43.

[45] See supra note xxxi.

[46] Please see State of Bombay v. Narasu Appa Mali AIR 1952 Bombay 84; Sri Krishna v. Mathura Ahir and Others AIR 1980 SC 707; P.E. Mathew v. Union of India AIR 1999 Ker. 345; Ahmedabad Women Action Group (AWAG) v. Union of India (1997)3 SCC 573.

[47] The Supreme Court in its order held that- "..the 1937 Act, insofar as it seeks to recognize and enforce Triple Talaq, is within the meaning of the expression "laws in force in Article 13(1) and must be struck down as being void to the extent that it recognizes and enforces Triple Talaq." Shayara Bano and Ors. v. Union of India (UOI) and Ors. 2017(9) SCALE 178.

[48] Mohd. Ahmed Khan v. Shah Bano Begum AIR 1985 SC 945.

[49] The controversy was with respect of interpreting the Arabic word "mata" to mean as "provision" that is one time lump sum payment or "maintenance" that is continued maintenance.

[50] See supra note xlix. 